\title{
Fumigate efficacy of Juniperus foetidissima essential oil and two terpenes against Phthorimaea operculella
}

\author{
GHALEB TAYOUB*, MALIK ALORFI, HALA ISMAIL
}

Department of Molecular Biology and Biotechnology

AECS, Damascus

PO Box 6091, Syria

*corresponding author: phone: +963 112132 580, fax: + 963116112 289, e-mail: scientific@aec.org.sy

\section{Summary}

Introduction: Potato (Solanum tuberosum L.) is an important vegetable crop in Syria. Potato tuber moth Phthorimaea operculella is the main damaging pest of this crop. Many approaches were tried to control it.

Objectives: This study evaluates the insecticidal activity of Juniperus foetidissima essential oil and two monoterpenes against potato tuber moth using fumigation bioassays.

Methods: Essential oil was extracted from new plant branches of Juniperus foetidissima using Clevengertype apparatus. Potato tuber moth Phthorimaea operculella, (adults, eggs, larvae, and pupae) were exposed to different concentrations of the essential oil of Juniperus foetidissima for various periods. The significance of differences between treatments at $p<0.05$ were evaluated by one-way analysis of variance using the mortality percentages data. The $\mathrm{LC}_{50}$ and $\mathrm{LC}_{90}$ were calculated by Probit analysis.

Results: Essential oil vapor with $\mathrm{LC}_{50}: 0.3 \mu \mathrm{l} / \mathrm{l}$ air was very effective against potato tuber moth at the adult stage. However; adults sensitivity to monoterpenes varied: Nerol caused a $100 \%$ mortality at $0.025 \mu \mathrm{l} / 1$ air after $6 \mathrm{~h}$, while the same concentration of citronellol caused $98 \%$ mortality. The $0.125 \mu \mathrm{l} / \mathrm{l}$ air concentration of the two compounds caused 100\% mortality after $6 \mathrm{~h}$.

Conclusion: Results suggest the possibility of using Juniperus foetidissima essential oil as a fumigant to control potato tuber moth infestation in stores.

Key words: Phthorimaea operculella, Juniperus foetidissima, essential oil, nerol, citronellol

Słowa kluczowe: Phthorimaea operculella, Juniperus foetidissima, olejek eteryczny, nerol, citronelol 


\section{INTRODUCTION}

Cultivated potato (Solanum tuberosum L.) is a crucial food crop in Syria. It is estimated that, (2017 data), the cultivated area in Syria is about 24376 hectares, with a total production of 562416 tons [1]. Many pests attack potato plants under field conditions. The most destructive pest for this crop is potato tuber moth, Phthorimaea operculella. This insect also attacks some other Solanaceae and Piperacae species in tropical, subtropical, and Mediterranean agro-zones [2- 4]. Many practices used by farmers to minimize the damage to tubers caused by potato tuber moth are useless. The use of synthetic organic pesticides against crops pests, although showing immediate and spectacular results, increases environmental pollution and causes health problems to humans as well as animals. Moreover, insects have developed resistance against synthetic insecticides and made them less effective [5]. Hence, there is a need for environment friendly and safer alternatives to control these pests.

Essential oils maintain protection for plants against bacteria, plant viruses, fungi, insects and herbivores. Those oils reduce herbivores appetite for such plants. Essential oils repel some insects and attracts some others for pollination or seeds dispersal. Plants essential oils have been suggested as an alternative source for insect control products $[6,7]$. Monoterpenoids extracted from essential oils have a role in defending plants. Some monoterpenoids are very toxic to insects, while others are repellent or have inhibitory effects [8-10]. Most of botanical insecticides have minor toxicity to non-target organisms, and rapidly biodegrade $[6,11]$. They also provide an alternative for resistance management as many botanical insecticides are highly effective against insecticidal-resistant pests [12-14].

Plant essential oils were suggested as appropriate agents in controlling pest infestation in stored products [15-16]. Monoterpenoids found in essential oils are volatile lipophilic compounds that can penetrate insects' bodies and disrupt their physiology. Because essential oils are highly volatile, they have fumigant action and are potential insecticides that might be used for controlling insects damaging stored crops [17-19].

The effect of seven vegetable oils against PTM adults were experimentally studied by Shelke $e t$ al. [20]. They found that neem oil (Azadirachta indica) in concentrations ranging between 0.05 and $0.1 \%$ had a deterrent effect on the PTM oviposition. Sharaby [21] reported that potato tuber moth reproduction was significantly reduced when males or females were exposed to orange peel oil vapor. That effect increased with the increase in oil concentration and exposure time. Moawad [22] reported an ovicidal activity of essential oils extracted from margorum, cardamom, rosemary and terpintin to PTM. Rafiee-Dastjerdi et al. [23] studied the insecticidal activity of the essential oil extracted from five different plant species, namely: basil, European pennyroyal, lavender, mint and savory on potato tuber moth. Sharaby et al. [24] used the bulb powder of Allium cepa to dust potato tubers and found that it was highly effective in reducing of the number of eggs deposited as well as reducing adult emergence. Juniperus foetidissima Willd. (Cupressaceae) grows in Syria. It has many uses because its wood resists damages caused by insects [25]. The components of its essential oil was previously reported by many authors $[17,26]$. The fungal growth inhibition activity of J. foetidissima and J. oxycedrus wood extracts was investigated by Balaban et al. 27].

The aim of this work is to evaluate the insecticidal effects of Juniperus foetidissima essential oil and two commercial monoterpenes on potato tuber moth infestation during storage period.

\section{MATERIALS AND METHODS}

\section{Essential oil extraction}

Newly branched sprouts of planted Juniperus foetidissima Willd were collected at the flowering period in May 2015, from Yafour area (Rif-Damascus, Syria) and the species was identified by Prof. M. Oudat (plant taxonomist, AECS). Plant material were initially air dried at room temperature for 7 days, then powdered. Clevenger-type apparatus was used to extract the essential oil by hydrodistillation for $3 \mathrm{~h}$ [28]. Essential oil yield was 1.4\% w/w (dry weight).

Gas chromatography analysis showed the presence of 22 compounds in Juniperus foetidissima essential oil. Main compounds were: citronellol (22.3\%), cadalene (19.1\%), and bornyl acetate (14.3\%) [17].

\section{Monoterpenoids}

A 95\% pure citronellol (the main constituent of J. foetidissima) and 99\% pure nerol (a well known monoterpen) standard material were purchased from Sigma-Aldrich. 


\section{Insects}

Adults, eggs, larvae, and pupae of potato tuber moth Phthorimaea operculella used in fumigation experiments were from a laboratory stock culture originally attained from natural field. Insect larvae and adults were fed and reared in jars under optimal culture conditions, (temperature, humidity and daynight cycle) [29].

\section{Fumigation experiments}

Three replicates of fumigation experiments for each concentration, life stage, and exposure time were conducted to test the insecticidal effect of the essential oil and the two monoterpenes: citronellol and nerol against potato tuber moth. The applied oil concentrations were chosen to identify the one that achieve a $100 \%$ mortality. Fumigation experiments were designed as reported in a previous study [10]. Adults and larvae were fumigated in jars, ( 1 liter air volume), while eggs and pupae, (3-5 days old), were fumigated in Petri dishes, $\left(160 \mathrm{~cm}^{3}\right.$ air volume). The tested doses of extracted oil on adults were: $0.15,0.25,0.50,0.75,1$ and $2 \mu \mathrm{l} / \mathrm{l}$ air, on eggs were: 0.05 , $0.25,0.50,0.75$ and $1 \mu \mathrm{loil} / 160 \mathrm{~cm}^{3}$ air, on larvae were: $0.05,0.10,0.50,1$ and $3 \mu \mathrm{l} / \mathrm{l}$ air, and on pupae were: 0.05 , $0.25,0.50,1,2$ and $6 \mu \mathrm{l} / 160 \mathrm{~cm}^{3}$ air. Adults mortality was determined $24 \mathrm{~h}$ post exposure. Hatched eggs percentage was calculated seven days post treatment. Larvae development was monitored for 40 days. Pupae mortality was determined by adult emergence after 7 days. Parallel control groups were also included.

The toxic effects of citronellol and nerol against adult insects (one day old) were investigated as reported in a previous study [10]. Adults were considered dead when no leg or antennal movements were observed.

Experiments mimicking the current situation in storing potatoes were conducted. Plastic barrels of 50 liters capacity were filled with twenty five kilograms of sound and fresh potato tubers. Slices of paper filters carrying insects eggs aged 24 and
48 h (792 eggs) were distributed within each barrel and on potato tubers. Filter papers measuring $3 \times 3 \mathrm{~cm}$ containing the concentration of plant essential oil which gave $100 \%$ mortality ( $1 \mathrm{ml} / 50 \mathrm{l}$ air), were placed within each barrel, then the barrels were closed tightly. The barrel was left for a mating period, (the period of hatching eggs), which lasted 10 days. The barrels were then opened and hatched eggs counted. Incubated tubers were observed six weeks later, (for one generation period), under laboratory conditions. Numbers of pupae and adults resulting from the first generation were recorded in kind and account for three independent experiments, in addition to the non-treated control. Statistical analysis and calculation of $\mathrm{LC}_{50}$ and $\mathrm{LC}_{90}$ were made according to our previous study [10].

Ethical approval: The conducted research is not related to either human or animal use.

\section{RESULTS}

Vapor of the essential oil extracted from the dried new leafy branches of $J$. foetidissima showed variable toxicity against potato tuber moth. This toxicity is associated with insect developmental stage, oil concentration and exposure time. Mortality significantly increased with increasing essential oil concentration. Exposure of adults to the highest dose of $2 \mu \mathrm{l} / \mathrm{l}$ air caused a $100 \%$ mortality after $24 \mathrm{~h}$ exposure period. Whereas, the lowest concentration used, i.e. $0.15 \mu \mathrm{l} / 160 \mathrm{~cm}^{3}$ air resulted in only $2 \%$ death after one day of exposure (fig. 1). $\mathrm{LC}_{50}$ for J. foetidissima essential oil on adults was $0.3 \mu \mathrm{l} / \mathrm{l}$ air, whereas the $\mathrm{LC}_{90}$ was $0.9 \mu \mathrm{l} / \mathrm{l}$ air (tab. 1). In the case of pupae, exposure to $6 \mu \mathrm{l} / 160 \mathrm{~cm}^{3}$ air $(37.5 \mu \mathrm{l} / \mathrm{l}$ air $)$ of the essential oil vapor resulted in $100 \%$ death of pupae after seven-day exposure period. The lowest concentration of $0.05 \mu \mathrm{l} / / 160 \mathrm{~cm}^{3}$ air $(0.31 \mu \mathrm{l} / \mathrm{l}$ air $)$ to which the pupae were exposed resulted in a $13 \%$ mortality after $24 \mathrm{~h}$ exposure period, (fig. 1). The $\mathrm{LC}_{50}$ of the essential oil on pupae was $4.97 \mu \mathrm{l} / \mathrm{l}$ air at $24 \mathrm{~h}$

Table 1

Calculated $\mathrm{LC}_{50}$ and $\mathrm{LC}_{90}$ values for Juniperus foetidissima essential oil against some different developmental stages of potato tuber moth (Phthorimaea operculella)

\begin{tabular}{llccccccc} 
P.operculella & $\begin{array}{l}\mathrm{LC}_{50} \\
\mu \mathrm{l} / \mathrm{l} \text { air }\end{array}$ & $\begin{array}{l}\mathrm{LC}_{90} \\
\mu \mathrm{l} / \mathrm{l} \text { air }\end{array}$ & Slope $\pm \mathrm{SE}$ & $\mathrm{F}_{\text {cal }}$ & $\mathrm{F}_{05}$ & d.f & $\chi^{2}$ & $\mathrm{P}$ \\
\hline Adults & 0.3 & 0.9 & $2.2 \pm 0.4$ & 35.9 & 7.7 & 5 & 9.5 & 0.0001 \\
\hline Eggs & 2.9 & 8.4 & $2.4 \pm 0.6$ & 14.97 & 10.13 & 4 & 7.8 & 0.0001 \\
\hline Pupae & 4.97 & 36.2 & $1.2 \pm 0.3$ & 19.8 & 6.6 & 6 & 11.07 & 0.0001 \\
\hline
\end{tabular}

Units: $\mathrm{LC}_{50}$ and $\mathrm{LC}_{90}-\mu \mathrm{l} / \mathrm{l}$ air, applied at $25 \pm 1^{\circ} \mathrm{C}$, d. f. - degrees of freedom 

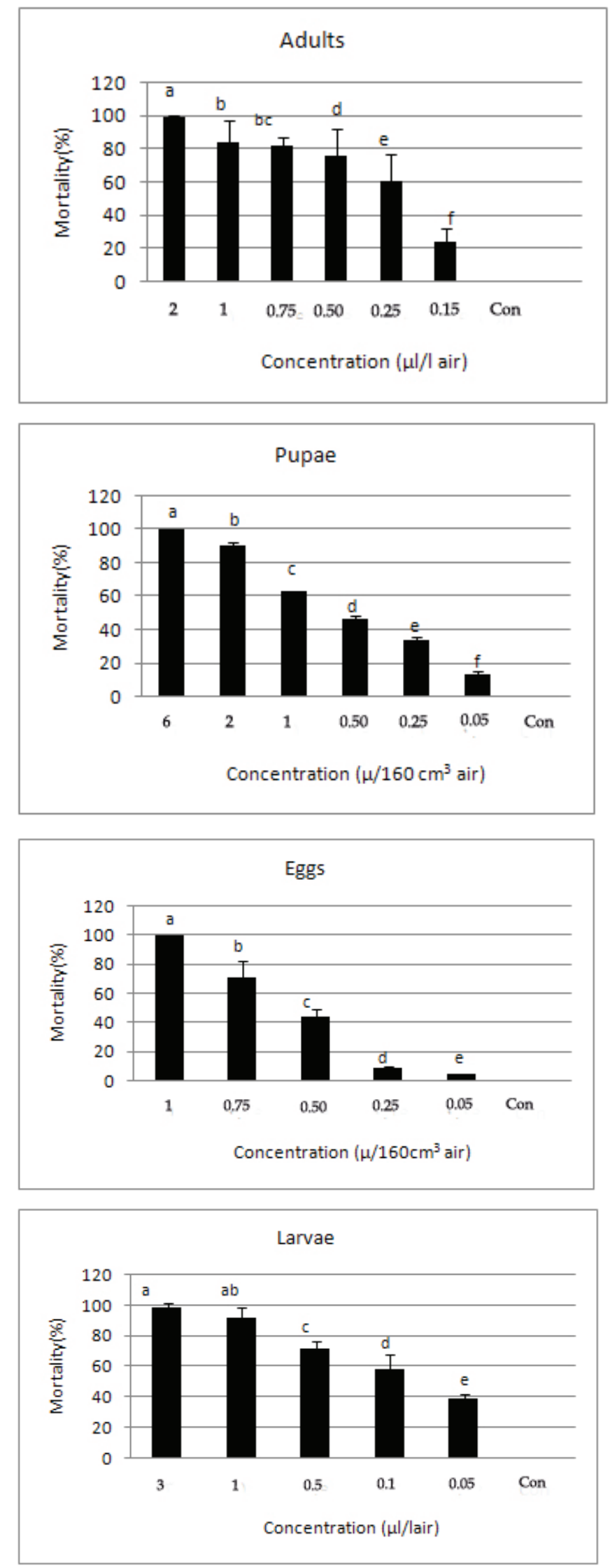

Figure 1

Mortality percentages of potato tuber moth(Phthorimaea operculella) stages due to treatment with different concentrations of Juniperus foetidissima oil. Means with same letters do not differ significantly at $p<0.05$ 
exposure period (tab. 1). Eggs appeared to be highly sensitive to toxic effect of $J$. foetidissima essential oil vapor; a $1 \mu \mathrm{l} / 160 \mathrm{~cm}^{3}$ air caused death of eggs by $100 \%$ after $24 \mathrm{~h}$ exposure period (fig. 1), with $\mathrm{LC}_{50}$ of $2.4 \mu \mathrm{l} / \mathrm{l}$ air (tab. 1). Larvae were highly affected with $3 \mu \mathrm{l} / \mathrm{l}$ air dose (fig. 1), potato tubers were free from infection. The $0.05 \mu \mathrm{l} / \mathrm{l}$ air dose showed a fumigant activity against PTM larvae but potato tubers were infected. This indicates for the need to apply higher doses to efficiently control this insect.

The two monoterpenes also showed insecticidal activity against adults of potato tuber moth with strong differences in mortality percentages depending on exposure time and concentration. As it was shown in figure 2 , nerol was relatively more toxic than citronellol. The nerol caused $97 \%$ mortality at $0.025 \mu \mathrm{l} / \mathrm{l}$ air concentration after $3 \mathrm{~h}$ of treatment. This mortality reached $100 \%$ when insects were exposed to nerol for 6 hours. The same concentration of citronellol caused a $91 \%$ and $98 \%$ mortality after $3 \mathrm{~h}$ and $6 \mathrm{~h}$ of exposure, respectively (fig. 2). However, at a dose of $0.125 \mu \mathrm{l} / \mathrm{l}$ air, each of the two compounds caused a $100 \%$ mortality 6 h of exposure (fig. 2).

Results obtained from treatment of PTM eggs in a plastic barrel with this essential oil showed that the oil vapor killed the eggs in a dose-dependent manner. At a concentration of $1 \mathrm{ml} / 50 \mathrm{l}$ air, the average number of hatching eggs was zero. None of the developed embryos inside the eggs was able to reach the last stage of development. All tubers were completely intact compared to the control (average number of hatching eggs 100\%). The concentration used to achieve this level of protection gives an idea of the importance of calculating the appropriate dose to protect potato tubers from this scourge during the storage of the crops.

\section{DISCUSSION}

The essential oil of J. foetidissima plants showed a high toxic effect on all developmental stages of PTM. The most sensitive life stage of PTM to J. foetidissima oil vapors was the adult and the larvae were the most tolerant. All adult insects were killed (100\% mortality), when they were exposed to $3 \mu \mathrm{l} / \mathrm{l}$ air concentration for $48 \mathrm{~h}$. The major compounds found in the essential oils of J. foetidissima have been reported previously to have a fungal growth inhibition [27], and an insecticidal activity
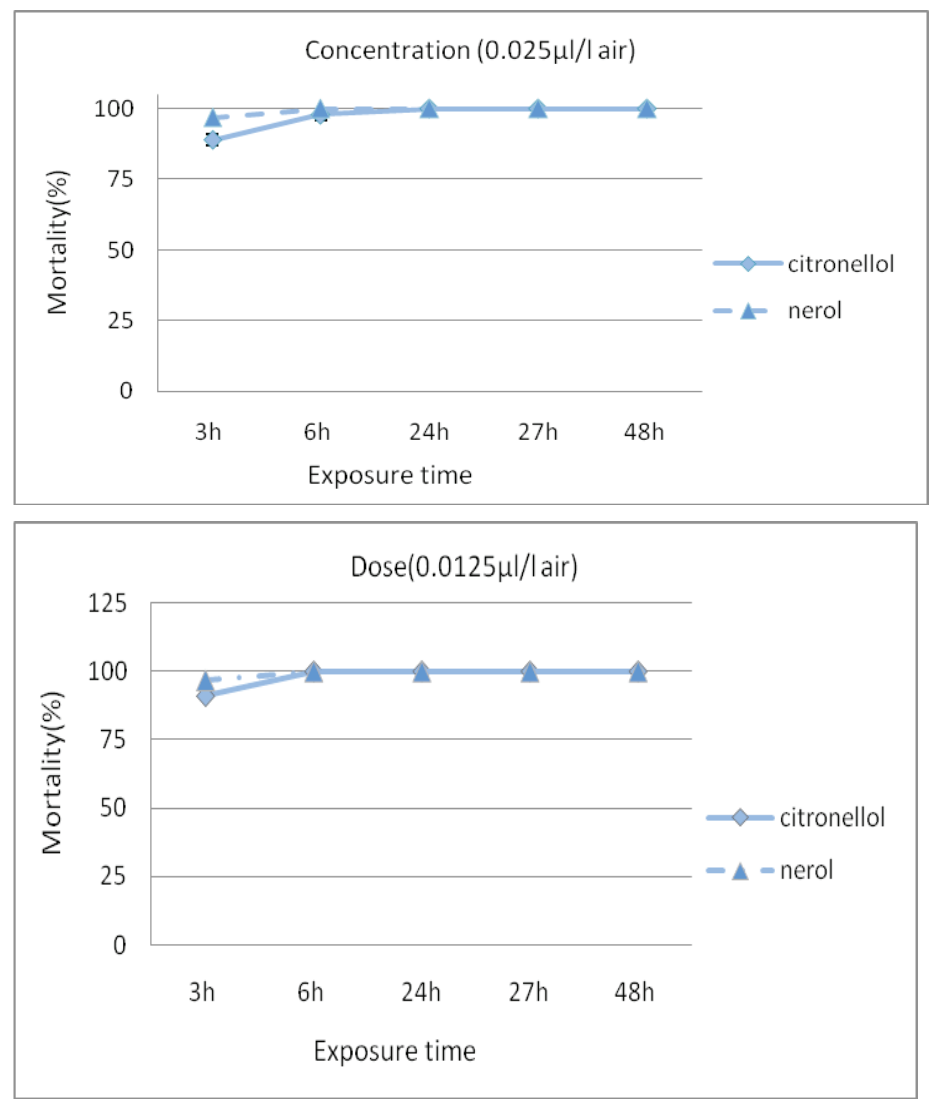

Figure 2

Mortality percentages of potato tuber moth (Phthorimaea operculella) adults exposed to monoterpenoids (citronellol, nerol) vapors for different periods 
against T. granaruim larvae [17]. Our results are \pm in agreement with results published by Tayoub et al. [10], Rafiee-Dastjerdi et al. [23], Sharaby et al. [24], Moawad \& Ebadah [30] who wrote that essential oils and their monoterpene components protect potato tubers against potato tuber moth infestation during storage.

On the basis of calculated $\mathrm{LC}_{50}$ values, J. foetidissima oil was substantially more toxic than lavander essential oil, the $\mathrm{LC}_{50}$ for J. foetidissima was 3 times lower. J. foetidissima oil was more toxic to one-dayold adults of $P$. operculella after $24 \mathrm{~h}\left(\mathrm{LC}_{50}\right.$ values were 0.3 and $0.9 \mu \mathrm{l} / \mathrm{l}$ air, for J. foetidissima and lavander, respectively). The J. foetidissima essential oil toxicity was almost similar to basil oil toxicity which has $\mathrm{LC}_{50}$ value of $0.108 \mu \mathrm{l} / \mathrm{l}$ air. However, mint and savory European pennyroyal oil have higher toxicity than J. foetidissima essential oil on PTM adults $\left(\mathrm{LC}_{50}\right.$ values were 0.048 and $0.065 \mu \mathrm{l} / \mathrm{l}$ air for mint and savory European pennyroyal oil, respectively) [23]. Differences observed in toxicity of plant essential oil between our results and Rafiee-Dastjerdi et al. [23], could be due to a number of reasons: the plant oil chemical composition that can be affected by season, growing region and weather conditions. Sensitivity of the insect species to the compounds found in the essential oil, the monoterpenes in particular, which represent a $51.4 \%$ of the total compounds found in the J. foetidissima essential oil [17]. Citronellol, the major compound in J. foetidissima (22.3\%) essential oil was used in perfumes and insect repellents [31], and as mosquito repellnt [32], and in biopesticides according to a document registered in the United States [33]. Exposure of Oryzaephilus surinamensis to citronellol for $14 \mathrm{~h}$ caused $100 \%$ mortality [34]. Bornyl acetate, the second most abundant compound of this essential oil tested (14.3\%) has shown fumigant toxicity against stored-product insects such as Sitophiles oryzae (L.) and Callosobruchus chinensis (L.) [35]. $\alpha$-Terpeneol and terpinene-4-ol have fumigant toxicity to $S$. oryzae [19]. The essential oils and their constituent monoterpenoids might act as neurotoxins [36]. Although the toxic effects of oil constituents used in the study have not been thoroughly investigated against humans and other mammals, available data for the use of plant materials containing monoterpenoids as pharmaceuticals and flavourings indicated no health side effects of their use. Therefore they are considered less harmful to humans than most conventional pesticides. In conclusion treatment of the potato tuber moth with J. foetidissima essential oil can safely protect potato tubers during storage period. Isolation of the active constituents of this essential oil will enables a detailed investigation of their toxic effects on insect pests.

\section{ACKNOWLEDGEMENTS}

The authors would like to express their thanks and gratitude to Professor Ibrahim Othman, Director General of Atomic Energy Commission of Syria and Professor Nizar Mir Ali for support and encouragement.

Conflict of interest: Authors declare no conflict of interest.

\section{REFERENCES}

1. Ministry of Agriculture. Annual agricultural satirical abstract. Syria 2015.

2. Westedt AL, Douches D, Pett W, Grafius E. Evaluation of natural and engineered resistance mechanisms in Solanum tuberosum for resistance to Phthorimaea operculella (Lepidoptera: Gelechiidae). J Econ Entomol 1998; 91(2):552-556. doi: http://dx.doi.org/10.1093/jee/91.2.552

3. Keasar T, Sadeh A. The parasitoid Copidosoma koehleri provides limited control of the potato tuber moth, Phthorimaea operculella, in stored potatoes. Biol Control 2007; 42(1):55-60. doi: http:// dx.doi.org/10.1016/j.biocontrol.2007.03.012

4. Golizadeh A, Esmaeili N. Comparative life history and fecundity of Phthorimaea operculella (Lepidoptera: Gelechiidae) on leaves and tubers of different potato cultivars. J Econ Entomol 2012; 105(5):18091815. doi: http://dx.doi.org/10.1603/EC12144

5. Kivan M. Effects of azadirachtin on the sunn pest, Eurygaster integriceps Put. (Heteroptera, Scutelleridae) in the laboratory. J Cent Eur Agr 2005; 6(2):157-160.

6. Isman MB. Plant essential oils for pest and disease management. Crop Prot 2000; 19:603-608. doi: http://dx.doi.org/10.1016/S0261-2194(00)00079-X

7. Libs E, Salim E. Formulation of essential oil pesticides technology and their application. Agri Res Tech 2017; 9(2):555759. doi: http://dx.doi.org/ 10.19080/ARTOAJ.2017.09.555759 
8. Tunç I, Erler F. Repellency and repellent stability of essential oil constituents against Tribolium confusum [Abschreckende Wirkung der Komponenten von ätherischen Ölen auf Tribolium confusum und die Beständigkeit dieser Wirkung]. Zeitschrift für Pflanzenkrankheiten und Pflanzenschutz/ J Plant Dis Protect 2003; 110(4):394-400.

9. Sim MJ, Choi DR, Ahn YJ. Vapor phase toxicity of plant essential oils to Cadra cautella (Lepidoptera: Pyralidae). J Econ Entomol 2006; 99(2):593598. doi: http://dx.doi.org/10.1093/jee/99.2.593

10. Tayoub G, Alorfi M, Ismail H. Fumigant toxicities of essential oils and two monoterpenes against potato tuber moth (Phthorimaea operculella Zeller). Herba Pol 2016; 62(4):82-96. doi: http:// dx.doi.org/10.1515/hepo-2016-0024

11. Hu D, Coats J. Evaluation of the environmental fate of thymol and phenethyl propionate in the laboratory. Pest Manag Sci 2008; 64(7):775-779. doi: http://dx.doi.org/10.1002/ps.1555

12. El-Wakeil N. Botanical pesticides and their mode of action. Gesunde Pflanzen 2013; 65:125149. doi: http://dx.doi.org/10.1007/s10343-0130308-3

13. Schmutterer H. Control of diamondback moth by application of neem extracts. In: Talekarand S, Griggs Td (eds.). Diamondback moth management and other crucifer pests. Proceedings of the $2^{\text {nd }}$ International Workshop, Asian Vegetable Research and Development Center, Shanhua, Taiwan 1992:325-332.

14. Ahn, YJ, Kwon M, Park HM, Han CG. Potent insecticidal activity of Ginkgo biloba-derived trilactone terpenes against Nilaparvata lygens. In: Hedin PA, Hollingworth RM, Masler EP, Miyamoto J, Thompson DG. (eds.). Phytochemicals For Pest Control ACS Symp., Ser. 658, Am Chem Soc Columbus, OH 1997:90-105.

15. Pawar V, Thaker V. In vitro efficacy of 75 essential oils against Aspergillus niger. Mycoses 2006; 49(4):316-323. doi: http://dx.doi.org/10.1111/ j.1439-0507.2006.01241.x

16. Abad MJ, Ansuategui M, Bermejo P. Active antifungal substances from natural sources. Arkivoc 2007; 7:116-145. doi: http://doi.org/10.3998/ ark.5550190.0008.711
17. Tayoub G, Odeh A, Ghanem I. Chemical composition and efficacy of essential oil from Juniperus foetidissima Willd against the Khapra Beetle. Int J Med Arom Plants 2012; 2(3):501-508.

18. Ahn YJ, Lee SB, Lee HS, Kim GH. Insecticidal and acaricidal activity of carvacrol and $\beta$-thujaplicine derived from Thujopsis dolabrata var. hondai sawdust. J Chem Ecol 1998; 24(1):81-90.

19. Lee BH, Choi WS, Lee SE, Park BS. Fumigant toxicity of essential oils and their constituent compounds towards the rice weevil, Sitophilus oryzae (L.). Crop Prot 2001; 20(4): 317-320. doi: http://dx.doi.org/10.1016/s0261-2194(00)00158-7

20. Shelke S, Jadhav L, Salunkhe G. Ovipositional and adult repellent action of some vegetable oils/ extracts against potato tuber moth. J Maharashtra Agric Univ Coll Agric 1985; 10(3):284-286.

21. Sharaby A. Effect of orange, Citrus sinensis (L.) peel oil on reproduction in Phthorimaea operculella (Zell.). Insect Sci Appl 1988; 9:201-203. doi: http://dx.doi.org/10.1017/S174275840000597X

22. Moawad S. Utilization of some natural materials for protection of the potato crop from insect infestation. Ph. D. thesis. Faculty of Science, Ain Shams University 2000, pp. 162.

23. Rafiee-Dastjerdi H, Khorrami F, Razmjou J, Esmaeilpour B, Golizadeh A, Hassanpour M. The efficacy of some medicinal plant extracts and essential oils against potato tuber moth, Phthorimaea operculella (Zeller) (Lepidoptera: Gelechiidae). J Crop Prot 2013; 2(1):93-99. doi: http://dx.doi.org /10.1080/03235408.2013.858879.

24. Sharaby A, Abdel-Rahman H, Abdel-Aziz SH, Moawad S. Susceptibility of different potato varieties to infestation by potato tuber moth and role of the plant powders on their protection. IOSR J Agric and Vetr 2014; 6(4):71-80. doi: http:// dx.doi.org/10.9790/2380-07417180

25. Tunalier Z, Kirimer N, Baser K. The composition of essential oils from various parts of Juniperus foetidissima. Chem Nat Compd 2002, 38(1):43-47. doi: http://dx.doi.org/10.1023/a:1015725630556

26. Uçar G, Balaban M. The composition of volatile extractives from the wood of Juniperus excelsa, Juniperus foetidissima and Juniperus oxycedrus. 
Holz als Roh 2002; 60(5):356-362. doi: http:// dx.doi.org/10.1007/s00107-002-0316-y

27. Balaban M, Atik C, Uçar G. Fungal growth inhibition by wood extracts from Juniperus foetidissima and J. oxycedrus. Eur J Wood Wood Prod 2003; 61(3):231-232.

28. Clevenger JF. Apparatus for the determination of volatile oil. J. Am Pharm Assoc 1928; 17:345-349. doi: http://dx.doi.org/10.1002/jps.3080170407

29. Saour G, Makee H. Radiation induced sterility in male potato tuber moth Phthorimaea operculella Zeller (Lep. Gelechiidae). J Appl Entomol 1997; 121(1-5):411-415. doi: http://dx.doi. org/10.1111/j.1439-0418.1997.tb01427.x

30. Moawad SS, Ebadah IMA. Impact of some natural plant oils on some biological aspects of the potato tuber moth, Phthorimaea operculella (Zeller)(Lepidoptera; Gelechiidae). Res J Agr Biol Sci 2007; 3(2):119-123.

31. Taylor WG, Schreck CE. Chiral-phase capillary gas chromatography and mosquito repellent activity of some oxazolidine derivatives of $(+)-$ and (-)- citronellol. J Pharm Sci 1985; 74(5):534-539. doi: http://dx.doi.org/10.1002/jps.2600740508

32. Revay EE, Kline DL, Xue R-D., Qualls W A, Bernier UR, Kravchenko VD, Ghattas N, Pstygo I, Muller GC. Reduction of mosquito biting- pressure: spatial repellents or mosquito traps. A field comparison of seven commercially available products in Israel. Acta Trop 2013; 127(1): 63-68. doi: http://dx.doi.org/10.1016/j.actatropica.2013.03.011

33. USEPA (U. S. Environmental Protection Agency) (un-dated). Citonellol (PC Code 167004), Biopesticide Registration Action Document. Office of Pesticide Programmers, Biopesticide and Pollution Prevention Division, U. S. Environmental Protection Agency, Washington D. C., USA. Available online at: http://www.epa.gov/oppbppdl/biopesticides/ingredients/tech_docs/brad_167004.pdf

34. Lee S, Peterson C, Coats J. Fumigation toxicity of monoterpenoids to several stored product insects. J Stored Prod Res 2003; 39(1):77-85. doi: http:// dx.doi.org/10.1016/s0022-474x(02)00020-6

35. Park IK, Lee SG, Choi DH, Park JD, Ahn YJ. Insecticidal activities of constituents identified in the essential oil from leaves of Chamaecyparis obtusa against Callosobruchus chinensis (L.) and Sitophilus oryzae (L.). J Stored Prod Res 2003; 39(4):375-384. doi: http://dx.doi.org/10.1016/ s0022-474x(02)00030-9

36. Grundy DL, Still CC. Inhibition of acetylcholinesterases by pulegone-1, 2-epoxide. Pest Biochem Physiol 1985; 23(3):383-388. doi: http:// dx.doi.org/10.1016/0048-3575(85)90100-2 